\title{
Size and selected characteristics of northern pike (Esox lucius L.) commercial and angling catches in Polish inland waters over the long term
}

\author{
Marek Trella, Arkadiusz Wołos
}

Received - 01 February 2021/Accepted - 18 May 2021. Published online: 30 June 2021; @Inland Fisheries Institute in Olsztyn, Poland Citation: Trella, M., Wołos, A. (2021). Size and selected characteristics of northern pike (Esox lucius L.) commercial and angling catches in Polish inland waters over the long term. Fisheries Aquatic \& Life 29, 108-123

\begin{abstract}
Northern pike (Esox lucius L.) is of great importance to inland commercial and recreational fisheries in Poland. Thanks to northern pike's substantial size, strength, the possibility of using a variety of fishing methods and techniques and various baits, and many other values, lake anglers value this species above all others. Additionally, for over a decade, northern pike has been the most widely stocked species in Polish inland waters of lakes, rivers and dam reservoirs. The aim of this work was to analyze in detail the size and characteristics of northern pike commercial fisheries and angling catches in Polish inland waters over the long term. The analyses were based on a compilation of traditional scientific papers, primarily analyses of commercial catches, and a review of the results of more than 40 years of studies on the size of northern pike angling catches. The analysis of research material indicated a steady decrease in commercial catches of this species in the years State Fisheries Enterprises (SFE) were in operation followed by relative stability in catches over the past two decades. The paper describes the methods used to estimate angling catches, namely questionnaire and catch-return (the so-called register) research. An increasing disproportion between the sizes of pike catches made with angling and commercial fishing gear was documented. Despite the problems presented in the paper related to estimating total pike catches, the analysis
\end{abstract}

\section{Trella [ $\left.\Xi^{\circ}\right]$, A. Wołos}

Department of Fisheries Bioeconomics, Stanisław Sakowicz Inland

Fisheries Institute in Olsztyn,

ul. Oczapowskiego 10, 10-719 Olsztyn, Poland

E-mail: m.trella@infish.com.pl revealed that anglers catch eightfold more northern pike than do commercial fishers.

Keywords: northern pike, catches, commercial statistics, questionnaires, catch register surveys

\section{Introduction}

Northern pike is important to inland commercial and recreational fisheries in Poland since this species is caught not only by commercial fishers, but primarily by anglers and mainly in lakes (Trella and Wołos 2015, Wołos et al. 2015, Mickiewicz 2016), and for years it has been the most preferred species among anglers fishing in lakes (Wołos 1991, Bnińska and Wołos 2001). Since the early 1990s, the role of the northern pike in lake fisheries management has become more important and is influenced by factors such as the increasing economic significance of recreational fisheries and increased prices and decreased supply of eel stocking material, which, in the 1970s and 1980s, was the most important fish economically in commercial lake fisheries (Wołos 2000, Mickiewicz 2012). The increased significance of northern pike led to the beginning of research on methods for managing its populations (Zakęś et al. 
2015, Czarkowski and Kapusta 2016) and the effectiveness of stocking with this species (Szczepkowski et al. 2012, Mickiewicz 2013, Kapusta 2015). This is especially significant since for more than a decade now, northern pike has been the top species of those stocked in Polish inland waters including lakes, rivers, and dam reservoirs (Mickiewicz and Wołos 2012).

In addition to the northern pike's obvious economic role, even more important is its environmental one that is not just limited to predation, but is more complex. Northern pike is one of the most important elements of aquatic ecosystems (Lampert and Sommer 2001, Craig 2008, Forsman et al. 2015, Czarkowski and Kapusta 2016). Northern pike is a keystone species for three main reasons. The first is its fish population regulatory role; namely, it eliminates individuals that are overproducing or are weak or diseased, including younger and smaller pike through cannibalism, which plays a primary role in the population dynamics of other fishes and invertebrates (Craig 2008). Its second role is ecological because it eliminates planktivorous fishes, including small-sized cyprinids, which increases zooplankton abundance in water bodies and limits increases of phytoplankton biomass that can improve water quality (Mehner et al. 2004). The third role is a stimulatory one in that northern pike influences the foraging intensity or the locations inhabited by other species. When northern pike inhabit water bodies, European whitefish (Coregonus lavaretus (L.)) populations must respond to this threat with various strategies: avoiding northern pike by foraging in the pelagic zone at the cost of limited growth or foraging in the littoral zone and delaying maturation to achieve sizes that are less susceptible to predation (Öhlund 2012). Northern pike predation not only influences the abundance and biomass of prey, but also morphological characters such as environmental adaptations, in particular body shape, and behavior; thus, one can conclude that, in addition to many other factors, it influences the evolution of prey species (Craig 2008). Conversely, decreases of northern pike abundance affect ecosystems in which it plays an important role as a predator, and its disappearance from the top of the food chain does not only lead to shifts in the trophic pyramid, but also to serious transformations in ecosystems themselves. This phenomenon occurred in the coastal zone of the Baltic Sea, where commercial and recreational catches targeted mainly larger predatory individuals such as perch (Perca fluviatilis L.), pikeperch (Sander lucioperca (L.)), and northern pike, and cormorant pressure caused decreases in predator abundance. This, in turn, permitted the three-spined stickleback (Gasterosteus aculeatus L.) population, which had previously been limited by predators, to increase almost fifty-fold in the coastal zone (Donadi et al. 2017, Nilsson et al. 2019, Eklöf et al. 2020). Such a large three-spined stickleback population, in addition to other environmental and anthropogenic factors, led to changes in the trophic pyramid that resulted in frequent algal blooms, bottom vegetation degradation, and increased eutrophication (Eriksson et al. 2009, Eriksson et al. 2011, Eklöf et al. 2020).

The greatest threat to the northern pike population, apart from overfishing, is the loss of natural spawning grounds (Larsson et al. 2015). The phenomenon of the disappearance of breeding sites is related not only to human activity, but also to climate change. Climate models indicate that further climate warming might cause changes in precipitation frequency and reduce snow cover that will result in lower quantities of water during the melt season and increased evapotranspiration (Neumann 2010, Wake 2012). Consequently, potential spawning grounds might arise faster in the event of increased rainfall or, inversely, the lack of melt water flowing to these areas might cause current spawning grounds to dry out and could prevent periodic spawning grounds from forming (Larsson et al. 2015). Therefore, it is understandable that the fishers surveyed who exploit the commercial fisheries of dam reservoirs mentioned northern pike as the species most threatened by progressing climate change (Trella et al. 2019). It follows that environmental changes related to persistent climate change can have both positive and negative effects on northern pike populations; therefore, this study is part of a body of publications comprising the doctoral thesis entitled 
"The effects of climate change and stocking programs on the effectiveness of fisheries management based on information obtained from fishery users of inland waters" and it demonstrates how catches of this species have changed over the long term from times when the effects of climate change were not yet noted to the present time when these effects are already beginning to occur.

The aim of this study was to analyze in detail the size and characteristics of commercial and recreational catches of northern pike in Polish inland waters over the long term.

This study was based on a compilation of traditional scientific papers that mainly focused on commercial catches and a review of the results of over 40 years of research by scientists from the Department of Fisheries Bioeconomics, the work of whom was published in scientific papers that focused primarily on the results of survey research conducted among recreational fishers. However, the review also included an even larger number of reports on the results of recreational catch registers that appeared in publications or unpublished studies usually conducted on large surface areas of water bodies for districts of the Polish Angling Association (PAA). Consequently, this present study presents data on the size and some characteristics of catches of northern pike over long periods of time.

\section{Materials and methods}

This work was created based on studies conducted over many years at the Department of Fisheries Bioeconomics, Stanisław Sakowicz Inland Fisheries Institute (IFI) in Olsztyn. The following were used in the present study:

- archival data from the Department of Fisheries Bioeconomics on nationwide lake fish catches in the 1956-1985 when State Fisheries Enterprises (SFE) were in operation;

- data on the level of nationwide commercial lake fisheries catches in the 1996-2018 period obtained from surveyed lake fisheries enterprises;
- data regarding employed commercial lake fishers to determine changes in the numbers of them in the 1996-2018 period;

- data regarding the lake surface area exploited by fisheries enterprises to determine changes in the lake surface area per fisher in the 1996-2018 period;

- the data above on employment and lake surface area were used to determine the level of catches of northern pike per lake fisher in the 1996-2018 period;

- fisheries data from the SFE Giżycko and "Śniardwy" Fisheries Enterprise Ltd., to show changes in commercial fisheries catches of northern pike in Lake Śniardwy in the 1960-2019 period;

- data from obligatory RRW-23 statistical questionnaires to determine the state of northern pike management following the political and ownership transformation and to make a comparative analysis of methods for collecting fisheries data;

- data from survey studies of anglers on northern pike catches conducted in:

- 1978-1979 - the study was conducted in cooperation with the Main Board of the PAA - 1,100 questionnaires;

- 1978-1979 - studies of 35 lakes with a combined surface area of 35,200 ha that comprise the Great Masurian Lakes (GML) system - 126 questionnaires;

- 1986-1990 - study of 32 SFE lakes (combined surface 27,883 ha) and 10 PAA lakes (surface 248 ha) - 591 questionnaires;

- 2014 - survey study of anglers regarding recreational fisheries in lakes exploited by eight fisheries enterprises with a combined surface area of 29,700 ha - 638 questionnaires;

- 2016 - survey study in cooperation with the Main Board of the PAA, the main districts of the PAA in 18 districts, and also anglers fishing in lakes exploited by three commercial fisheries enterprises in Ełk, Wągrowiec, and Bogucin - 936 questionnaires. 
- data from recreational fisheries catch registers regarding catches of northern pike from the following years:

- 1986 - 5,222 catch registers from the Słupsk district of the PAA;

- 1986 - 1,980 catch registers from the Krosno district of the PAA;

- 1988 - 744 catch registers from the Suwałki district of the PAA;

- 2004 - 13,060 catch registers from four PAA districts in southwest Poland (Jelenia Góra, Legnica, Wałbrzych, and Wrocław);

- 2017 - 2,518 catch registers from the Bielsko-Biała district of the PAA;

- 2017 - 30,683 catch registers from the Katowice district of the PAA;

- 2017 - 7,809 catch registers from the Mazovian district of the PAA.

- 2017 - 11,435 catch registers from the Torun district of the PAA.

The work used basic statistical parameters, such as percentages, means, determination coefficients, regression models to show trends, and time series analysis, and the threshold probability value was $\mathrm{p} \leq 0.05$. All calculations and figures were done in Microsoft Excel.

\section{Results and discussion}

\section{Fisheries catches of northern pike during the period of operation of the State Fisheries Enterprises}

From approximately 1950 to the beginning of the 1990s, the State Fisheries Enterprises (SFE) were the largest users of inland waters in Poland. In 1981, they exploited almost 280,000 ha of lakes, which was approximately $90 \%$ of the total lake area in Poland, and through the Central Fish Office, they supplied nearly $100 \%$ of the lake production of consumer fish (Report on the state...1981). During the period of operation of the SFE, a central system for collecting and collecting basic economic data was in place, which facilitated tracking basic parameters and trends characterizing the fisheries catches of northern pike in 1956-1985. With a mean size of 473 tons, the maximum catch was 779 tons in 1959 and the minimum was just 140 tons in 1984 . The catch trend declined $\left(r=-0.91, R^{2}=0.83\right)$ from more than 600 tons on average over nine years at the beginning of this period to approximately 200 tons on average in the last nine years (Fig. 1).

The next report stated, inter alia, the following:

...the evolution of catches of typical littoral species, i.e., northern pike and tench (Tinca tinca (L.)), shows a catastrophic decline in both these species. On average, catches of them decreased by about 26 tons per year, and in recent years decreases of them are already $40 \%$ of the long-term mean. These tendencies mentioned above prove that the process of environmental degradation of our lakes has already reached a degree that threatens not only the further development of lake fisheries, but even its very existence (State of and perspectives...1986).

Leopold et al. (1986) limited the causes of these changes to ongoing processes of accelerated eutrophication, one of the main indicator species of which is northern pike.

\section{Fisheries catches of northern pike after the period of political and ownership transformation}

The economic crisis of the 1980s, followed by political changes and ownership transformations in fisheries ${ }^{1}$ resulted in the lack of adequate information on the state of lake fisheries from the end of this decade until the mid 1990s. Along with the progressive ownership changes in fisheries, the importance of scientific

\footnotetext{
${ }^{1}$ After the fall of the communist regime in Poland in 1989, SFE were liquidated, and within a few years there were ownership changes involving the lease of the right to use the lakes for fishing purposes to new economic entities, mainly to various types of companies established mainly by former managers and employees of SFE and the Polish Angling Association. Thus, the total area of lakes under fisheries amounted to 270 thousand ha.
} 


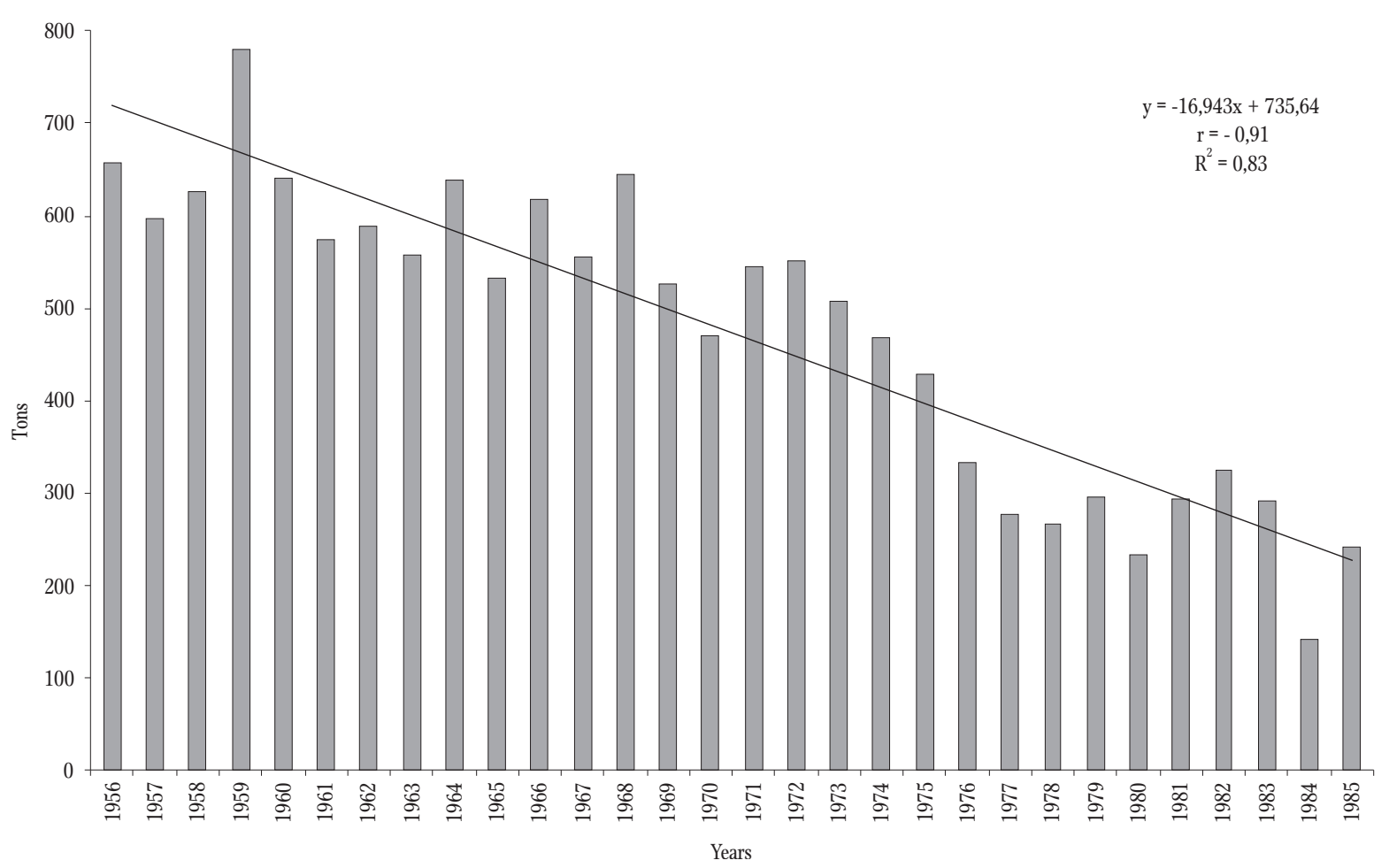

Figure 1. Commercial northern pike catches from lakes in 1956-1985.

research covering many aspects of the functioning of lake fisheries increased. In 1996, survey studies of lake fisheries enterprises were initiated, and since they included analyses of economic indicators (Leopold and Wołos 1996), this permitted more comprehensive, long-term analyses of northern pike catches in the 1996-2018 period. The mean annual catch of the lake surface area of 270,000 ha in this period was 268 tons (0.99 $\left.\mathrm{kg} \mathrm{ha}^{-1}\right)$, and for 18 years there were relatively small deviations (no trend, $\mathrm{R}^{2}$ - 0.12) from the given mean in different years (Fig. 2), but after 2014 catches decreased to a mean of approximately 230 tons $(0.85 \mathrm{~kg}$ $\left.\mathrm{ha}^{-1}\right)$. Current catches of northern pike remain of great importance economically and to the management of this fishery as is evidenced by the fact that in 2018 the total catch from lakes was 233 tons, which accounted for $12 \%$ of the catches of all species, and with its total monetary value of 2.58 million PLN, it contributed $14.33 \%$ to the overall value of catches of approximately 18 million PLN, which was the third most important contribution following eel, Anguilla anguilla (L.), and vendace, Coregonus albula (L.) (Wołos 2019a). It can also be concluded that despite the effects observed of climate change, this has not yet affected the economics of northern pike in lakes, which are already observed by those exploiting this fishery in dam reservoirs in Poland (Trella et al. 2019).

A separate study based on the obligatory RRW-23 statistical questionnaires was conducted on a sample of 390 fisheries enterprises that exploited 380,100 ha of flow-through lakes, rivers, and dam reservoirs, although not all fisheries users returned completed questionnaires, and it indicated that in 2018 total reported northern pike commercial fisheries catches were also 233 tons, including 50.3 tons of spawners, which was $21.6 \%$ of the total weight of northern pike caught, and $57.8 \%$ of the total catches of spawners of all the 22 fish species cultured under controlled conditions for stocking. We also discuss using the same statistical questionnaires to determine the size of angling catches in a subsequent section of this article.

In the period analyzed, there was a statistically significant decrease $\left(r=-0.87, R^{2}=0.75\right)$ in the number of commercial lake fishers (Fig. 3), which was consequential for the considerations presented herein. In the first five years (1996-2000) the number of commercial 


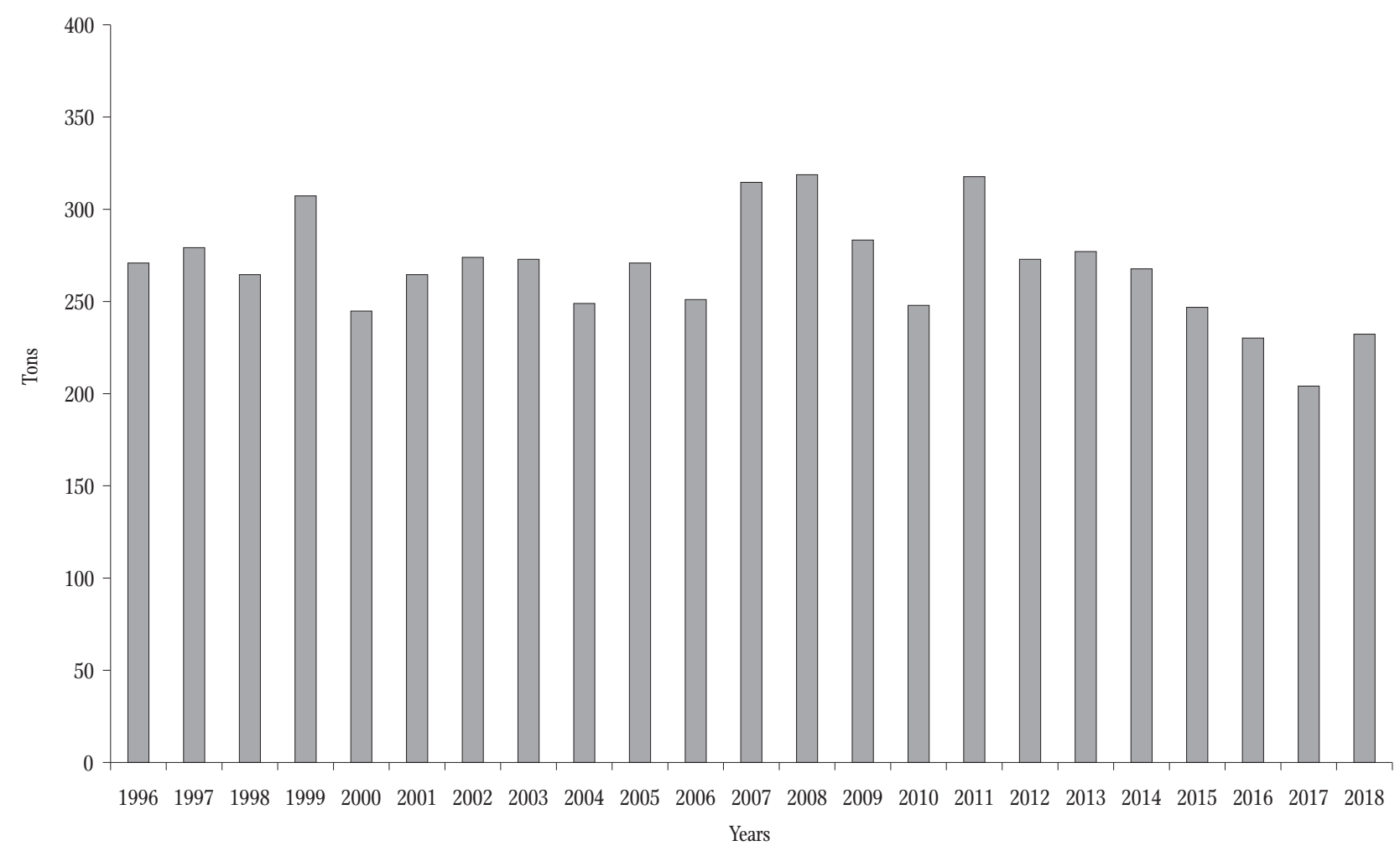

Figure 2. Commercial northern pike catches from lakes in 1996-2018.

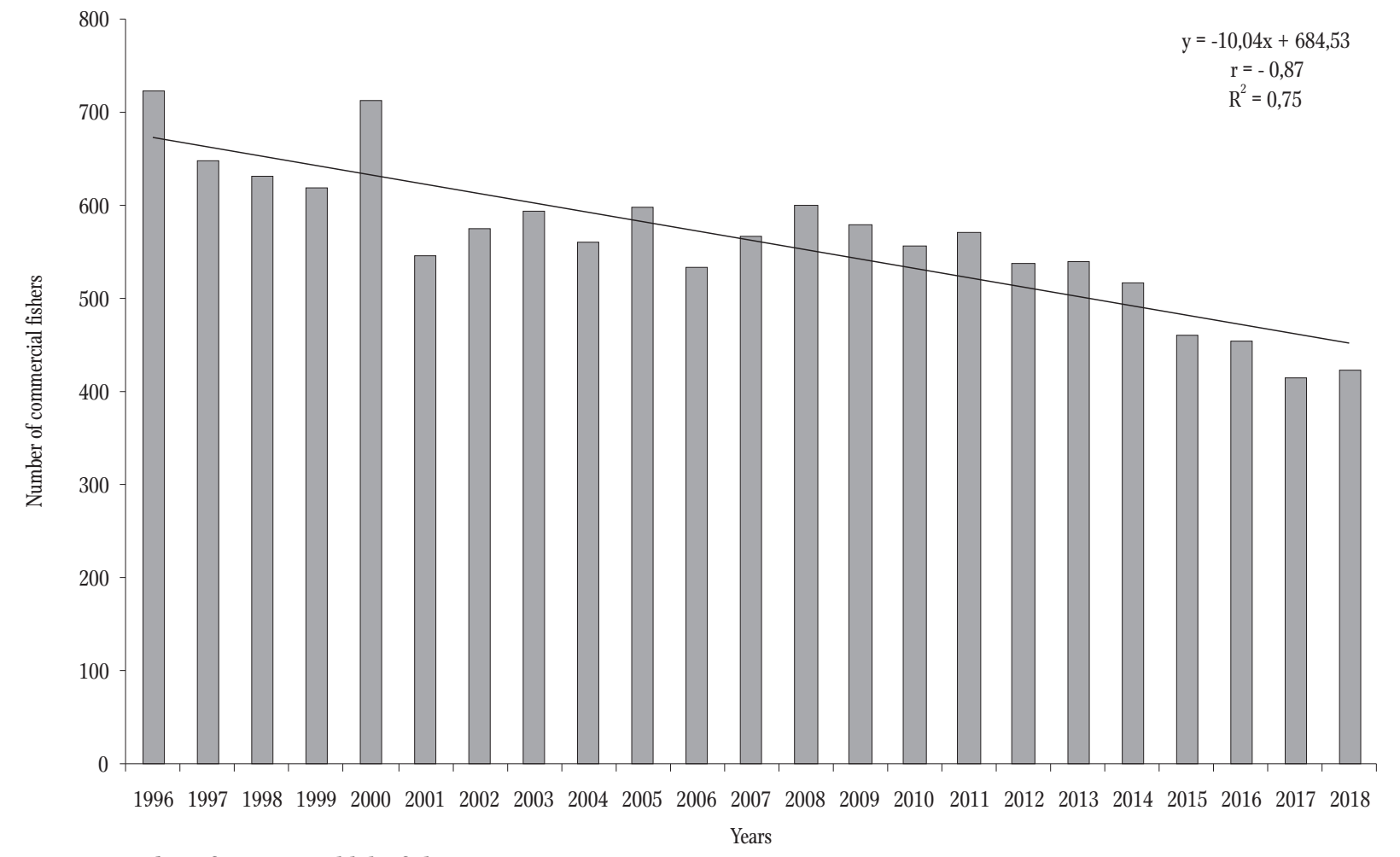

Figure 3. Number of commercial lake fishers in 1996-2018. 


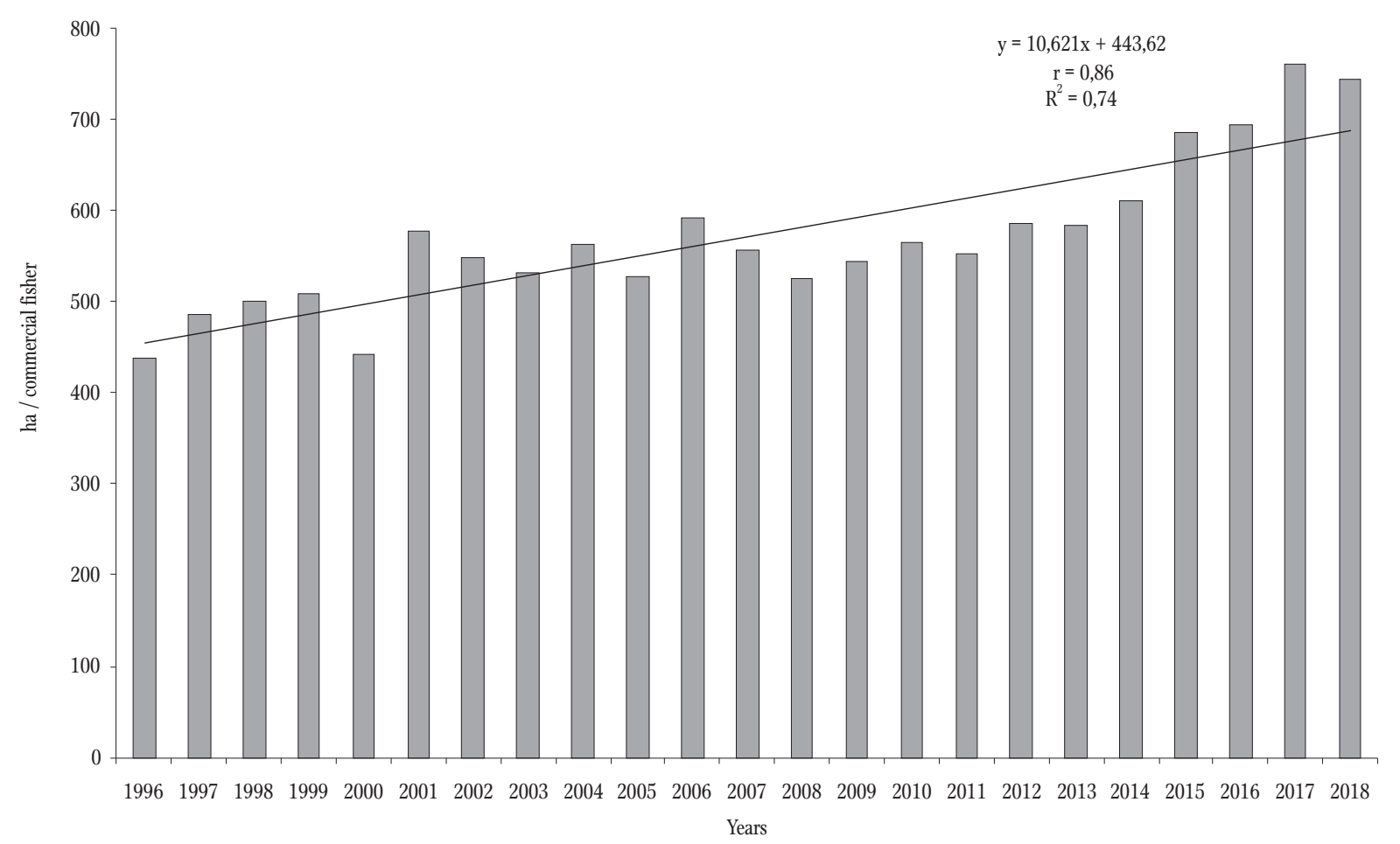

Figure 4. Mean lake surface area per commercial fisher in 1986-2018.

fishers averaged 667, while in the last five (2014-2018) there were 454 commercial fishers, which was a decrease of $32 \%$. The consequence of this decrease was a clear upward trend $\left(\mathrm{r}=0.86, \mathrm{R}^{2}=0.74\right)$ in the lake surface area per commercial fisher (Fig. 4); while in 1996-2000 this parameter averaged 475 ha and in the final five years of the period analyzed it increased by $47 \%$ to a mean level of 699 ha. These results suggest that the decrease in northern pike catches from lakes recorded in the last few years was not necessarily associated with the eutrophication processes mentioned above (Leopold et al. 1986), but was rather a consequence of the decreasing number of active commercial fishers, and, therefore, also a decrease in the intensity of the exploitation of northern pike with commercial fishing gears. With the observed decrease in the number of commercial fishers and the increase in the lake surface area per commercial fisher, it is worth noting that in the same period there was an increase in the mean annual catch of this species per commercial fisher $\left(r=0.69, \mathrm{R}^{2}\right.$ $=0.48$ ) (Fig. 5). This parameter was $413 \mathrm{~kg}$ in the first five years, while in the final five it was $521 \mathrm{~kg}$, which is an increase of $26 \%$. The reason for this might be, on the one hand, the increasing lake surface area per commercial fisher, and, on the other, the gradual decrease in fisheries pressure targeting the exploitation of less valuable cyprinid species, mainly small bream, roach, and silver bream, the catch of which is unprofitable because of low consumer demand and low prices, and the increasing intensity of the exploitation of valuable species with more selective fishing gears such as gill-nets.

\section{Fisheries catches of northern pike in Lake Śniardwy}

An interesting example of northern pike fishing exploitation is that in the largest lake in Poland, Lake Śniardwy (113.8 $\left.\mathrm{km}^{2}\right)$. In the $1960-2019$ period, the mean annual catch of this species was $15,606 \mathrm{~kg}$, which was $1.47 \mathrm{~kg} \mathrm{ha}^{-1}$, and two sub-periods can be distinguished. In the first one (1960-1988) was when SFE Giżycko was in operation, and, despite significant fluctuations, as many as 19 times catches exceeded 20 tons, with a maximum of 35 tons in 1968 (Fig. 6). Following this, a decrease was noted, and since the establishment 


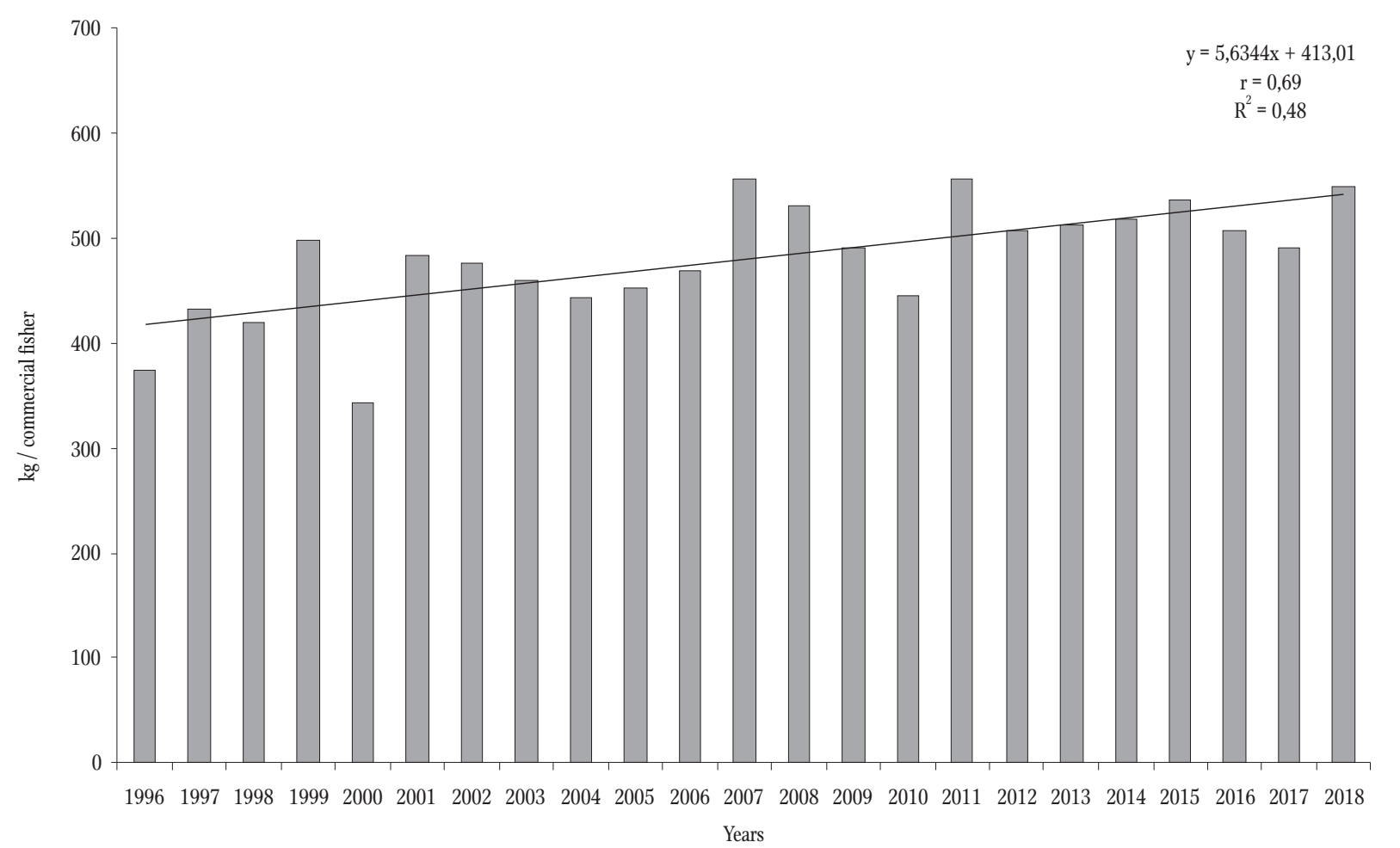

Figure 5. Northern pike catches per commercial lake fisher in 1996-2018.

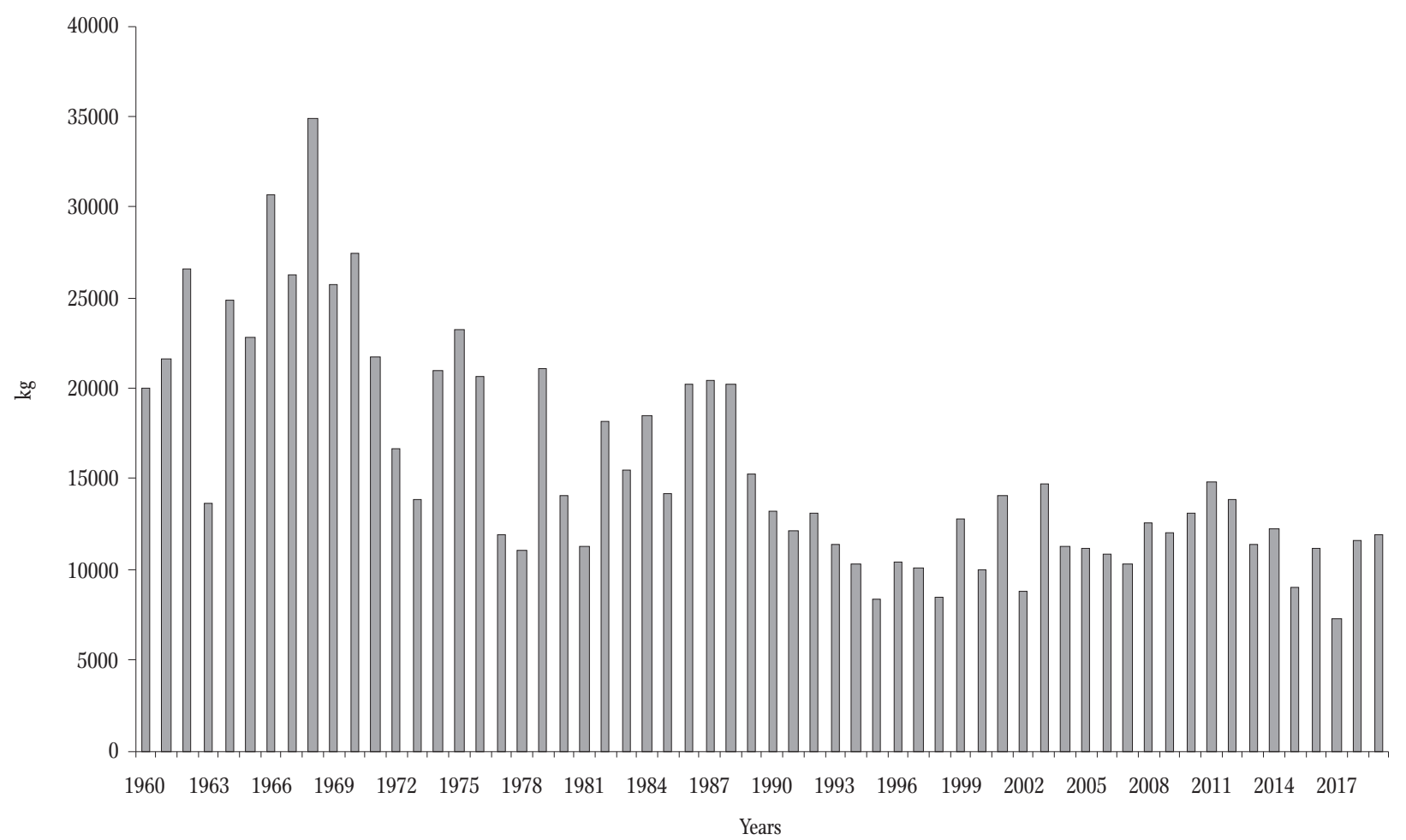

Figure 6. Commercial northern pike catches in Lake Śniardwy in 1960-2019. 
of a new entity, Śniardwy Fisheries Enterprise Ltd., in 1994, the mean catches have been 11 tons, but again fluctuations have been significant (Wołos 2018). The mean annual harvest in the last five years (2015-2019) decreased to $8,302 \mathrm{~kg}$ at a yield of $0.78 \mathrm{~kg} \mathrm{ha}^{-1}$. Specialists from this enterprise along with scientists from the Department of Lake Fisheries, IFI, concluded that one of the main reasons for the decrease in northern pike catches in the Lake Śniardwy complex was the large colony of great cormorants that is located on island of Lake Warnołty, a satellite one of Lake Sniardwy, that numbered in 2011-2018 from 1,169 to 1,447 nests, which was, at the time, the largest breeding colony of this species in northeastern Poland (Traczuk 2013, Wołos 2019b).

\section{Angling catches of northern pike - questionnaire surveys}

The first data regarding nationwide northern pike catches comes from the work of Leopold and Bnińska (1980), which included information obtained from surveys conducted in the $1978-1979$ period. The analysis was based on a randomly selected sample of 1,100 of 15,000 questionnaires received. Twenty-eight species occurred in the catches anglers caught in all 49 districts of the PAA, and the mean annual catch per angler was $54.3 \mathrm{~kg}$ of fish. In the catch structure, roach was first (17.5 kg, 32.2\%), and northern pike (9.1 kg, 16.8\%) was second. This study was the first in the Polish literature that examined angler preferences for species as it posed a question regarding which fish species the anglers would most like to catch. It turned out that these are not always the species they catch most frequently. On list of fish species preferred by fishers, northern pike was first, followed by carp (Cyprinus carpio L.) and roach (Rutilus rutilus (L.)) (Leopold and Bnińska 1980, 1987).

Based on the analysis of data from 126 questionnaires collected in 1978-1979, an attempt was made to determine the size of the northern pike angling catches in 35 lakes with a total area of 35,200 ha that comprise the Great Masurian Lakes (GML). With the mean annual catch of northern pike at $11.6 \mathrm{~kg}$ per angler, it was calculated that local anglers caught 105 tons and visiting anglers caught 33 tons; thus, total northern pike catches were approximately 140 tons, which was nearly fourfold the total fisheries catch of SFE Giżycko of this species from the GML (Wołos 1984).

In the 1986-1990 period, research was conducted on many aspects of lake angling, the results of which became the basis of the first doctoral dissertation in Poland on angling (Wołos 1992). Although of a slightly different focus from the main goal of the present study, some of these results are currently extremely relevant, and since some of them have not yet been published, it is worth referencing them here. For this study a total of 591 questionnaires were collected from anglers fishing in 32 SFE lakes and 10 PAA lakes with a total area of 27,883 ha, which at that time was about $10 \%$ of the total area of lakes used for fisheries in Poland. The share of northern pike in angling catches from SFE lakes was about $16 \%$, while in PAA lakes it was higher at $19.1 \%$, while in the former group the percentage of angling catches was almost fourfold higher than of fisheries catches. The largest shares of northern pike catches were from the following lakes: Kozie (71.6\%), Starżno (67.7\%), Dymno (44.2\%), Łąka (38.7\%) and Mamry Północne (36.5\%). The lake anglers’ preferred species in descending order were as follows: northern pike, eel, perch, pikeperch, and, not until fifth place, the cyprinid species common bream (Abramis brama (L.))

The main features of anglers who tolerate greater angling pressure at fishing grounds and those who require much more space for successful fishing were also examined, and this group included anglers that preferred predatory species. It was revealed that anglers from the first group used boats for fishing less frequently (36.3\% in comparison to $58.5 \%$ from the second group), caught northern pike and perch much less frequently (33.4\% of all fish catches in comparison to $52.8 \%$ among the second group), and considered northern pike the most favored species to a lesser degree than did the anglers who required much greater distance from other anglers. These are 
two clearly different groups of anglers, as evidenced by the fact that as motivation for fishing, $44.3 \%$ of the first group reported it was for sport and $44.3 \%$ for consumption, while in the second group these values were $60.8 \%$ and $27.5 \%$, respectively.

The result of the analysis of changes in fisheries management that the anglers desired was noteworthy: $48 \%$ of them responded that they would like to see increased stocking (especially of northern pike), $20.4 \%$ reduced commercial catches, $10.0 \%$ bans on electrofishing, and $6.6 \%$ the observation of spawning periods. However, among proposed changes to regulations governing angling, the demand for greater northern pike protection through lowering daily limits and increasing protected sizes was proposed by $6.2 \%$ of the anglers surveyed, which was in fifth position. These expectations remain valid 30 years after the study cited.

Among the largest northern pike mentioned by the anglers surveyed were 15 specimens exceeding 9 $\mathrm{kg}$ (which was the standard at the time for winning a official bronze medal), and two of them significantly exceeded the weights of the others. The first angler, who was interviewed in person by one of the authors of the study on the shores of Lake Wigry in 1986, was an elderly gentleman who reported catching in 1962 a live northern pike $143 \mathrm{~cm}$ long that weighed $33.0 \mathrm{~kg}$. The weights and dimensions of other large fishes he reported catching (European whitefish, bream, roach, and perch) indicated that, at that time, Lake Wigry was a very attractive fishing ground. Another record-breaking northern pike specimen, according to a second angler surveyed, was caught in 1985 in Lake Mamry Północne, which measured $127 \mathrm{~cm}$ and weighed $25.7 \mathrm{~kg}$. It should also be mentioned that these two large, deep lakes (Wigry - surface area of $21.7 \mathrm{~km}^{2}$ and maximum depth of $73 \mathrm{~m}$; Mamry Póůnocne - surface area of $25.04 \mathrm{~km}^{2}$ and maximum depth of $43.8 \mathrm{~m}$ ) were among the cleanest in Poland years ago, and they had very abundant stocks of vendace and European whitefish, which the oldest northern pike age classes preyed upon, and unlike few other lakes they provided conducive conditions for numerous northern pike populations, and most importantly, this species could reach significant, even record, sizes in them. This was confirmed by the fact that among the 15 specimens mentioned by the anglers, six were reported to have been caught in Lake Mamry Północne. It is also worth mentioning the data on the growth rates of northern pike in more than a dozen lakes in the vicinity of Węgorzewo (inter alia, lakes Mamry, Święcajty, Rydzówka, and Gołdopiwo), which indicated that the northern pike from Lake Mamry was characterized by the fastest growth rate and reached lengths (lc) at age $6+$ of approximately $80 \mathrm{~cm}$. In the second lake in the ranking, Lake Sołtmany, it reached lengths of $65 \mathrm{~cm}$, while in the last three lakes it reached lengths of 50-55 cm (Antosiak 1961).

In 2015, a survey of anglers was conducted on angling catches in 2014 in lakes exploited by eight fisheries enterprises located in three main lake regions, conventionally referred to as Mazury, Pomorze, and Wielkopolska (Wołos et al. 2015). The total lake surface area under the supervision of these entities was 29,700 ha and was $11 \%$ of the total area of lakes exploited for fisheries in Poland. Based on the analysis of 638 surveys, it was calculated that the mean annual catch of all species per angler was 49.1 $\mathrm{kg}$, the mean daily catch was $1.42 \mathrm{~kg}$, and northern pike was from 5.0\% (Sława Fisheries Enterprise Ltd.), 24.2\% (Ełk Fisheries Enterprise Ltd.), and 29.5\% (Augustów private fisheries enterprise) of the total weight of the fishes caught. The mean share of northern pike in catches for eight entities was $17.0 \%$. The species preferred by anglers were northern pike, followed by perch and bream, with carp in sixth place. After taking into account the calculations above and data on the number of fishing permits (year-round, short-term, and single-day) sold by 84 fisheries enterprises (with a lake surface area of 186,000 ha), the total angling catches in Polish lakes in 2014 was estimated at 5,250 tons of fish, including 890 tons of northern pike, which was 3.2-fold more than the total fisheries catch of this species, which was 267 tons in 2014.

In 2016, the Department of Bioeconomics of Fisheries, in cooperation with the Main Board of the PAA, conducted a survey of anglers, mainly PAA members from 18 districts, and also those fishing in 
lakes exploited by three fisheries enterprises in Ełk, Wagrowiec, and Bogucina (Czarkowski et al. 2018). An analysis of 936 questionnaires showed that, in 2015, the mean catch per angler was $5.4 \mathrm{~kg}$ of northern pike, which was $11.7 \%$ of the total weight of the fishes caught. An analysis of the questionnaires form the survey sample showed that pikeperch was ranked first among preferred species, northern pike was second, and carp was third. The distinctly higher share of northern pike in lake catches (Wołos et al. 2015) than in the waters of the 21 entities surveyed (18 PAA districts and only three commercial lake fisheries enterprises) could, therefore, have resulted not only from conditions in the lakes that are more favorable to northern pike populations than those, for example, in rivers, which are almost entirely exploited by the PAA, but also the popularity of anglers voluntary practicing catch and release $(\mathrm{C} \& \mathrm{R})$ fishing with northern pike, but also because of the policies of many PAA districts that include a number of regulations to protect this species, which is preferred by anglers, more restrictively including larger minimum or fork sizes, C\&R, and even no kill.

\section{Angling catches of northern pike - studies of catch registers}

In the mid 1980s, angling research in Poland gained a new source of data, namely, angling catch registers; initially, this was on an experimental scale in two PAA districts, Słupsk (1986-1987) and Krosno (1986), then, for two years, in all PAA districts (1988-1989). After a break of several years, selected districts, namely Katowice and Bielsko-Biała, reactivated the mandatory registers (Wołos et al. 1998), and since early 2000, all members of PAA districts have been required to register catches (Wołos and Mickiewicz 2002).

Leopold et al. (1988) reported the results of an analysis of material from 1986, containing registers completed by 5,222 anglers from the Słupsk district of the PAA. In these registers, northern pike accounted for $16.4 \%$ of the total weight of fish caught, and the percentage of this species in SFE lakes was
18.2\%, while in PAA lakes it was $21.1 \%$. In 17 PAA lakes, the share of northern pike exceeded $30 \%$, including 12 of them in which it was higher than $40 \%$, and in three lakes - Smardzewo (87.7\%), Godzież (68.6\%) and Miłe (50.4\%) - it exceeded 50\%. These were usually shallow lakes with relatively small surface areas of fewer than 30 ha and of good environmental conditions and extensive littoral zones.

Also in 1986, catch registers from 1980 from the Krosno district of the PAA were analyzed (Wołos and Piskorski 1991). The majority of the waters in this district are those of the San River and its tributaries, including the Wisłok and Jasiołka rivers. In total, anglers caught 28 species of fish of a total weight of approximately 22 tons, and the most frequently caught species were grayling (Thymallus thymallus (L.)) at $33.0 \%$ of the total catch weight and chub (Squalius cephalus (L.)) at $16.2 \%$. Northern pike contributed $9.6 \%$ of the catch, and the highest mean weight of northern pike $(2.17 \mathrm{~kg})$ was recorded in the Myczkowce Dam Reservoir on the San River, and the lowest in the Sieniawa Reservoir $(1.16 \mathrm{~kg})$ on the Wisłok River.

In 1988, anglers from the Suwałki district of the PAA registered their catches, and Wołos and Grabowska (1990) reported on the results of the analysis of 744 catch registers from them. Angling catches of northern pike were $22.0 \%$ of the total weight of the fish caught, and the following lakes had the highest shares of this species: Pobłędzie (51.3\%), Kopane (54.4\%), Ożewo (40.1\%), Przechodnie (40.3\%), and Okminek (34.7\%). These lakes were slightly larger and deeper than those in the Słupsk district and were usually mesotrophic and inhabited by large stocks of perch, while some had stocks of coregonids and burbot (Lota lota (L.)). Most of these lakes were also exploited with commercial fishing gear.

In 2004, the PAA districts in Jelenia Góra, Legnica, Wałbrzych, and Wrocław, which are all in southwest Poland, cooperated to register catches and obtained a return of 13,060 registers, the analysis of which showed that northern pike was $9.2 \%$ of the total weight of all fish species caught, with the highest share of them caught in lowland rivers (12.5\%), 
followed by dam reservoirs (7.9\%), and mountain rivers $(5.1 \%)$. The percentage of northern pike angling catches in the largest of the rivers, the Oder, was $15.2 \%$ (Legnica district of the PAA), while in the largest of the dam reservoirs, the Mietków (800 ha), in the Wrockaw district of the PAA they were only $4.0 \%$. The mean weight of northern pike registered in all the angling catches in the four districts was relatively low at $1.50 \mathrm{~kg}$ (Wołos et al. 2006).

And what is the situation of northern pike that was assessed based on catches recorded by anglers now, 20-30 years after these studies? An attempt to answer this question was based on the results of registers from 2017 of four districts of the PAA in Bielsko-Biała, Katowice, Mazovian, and Torun and on data obtained from the analysis of official statistical questionnaires that must be completed by all commercial and angling entities exploiting the waters of fisheries zones including those in flow-through lakes, rivers, and dam reservoirs. In 2017, 2,518 anglers registered their catches made in the waters exploited by the Bielsko-Biała district of the PAA, and the total northern pike catch was 1,475 $\mathrm{kg}$, which was $9.4 \%$ of the total catch. The largest number of northern pike was caught in two dam reservoirs; Porąbka Reservoir (10.7\%) had the highest share, followed by Tresna Reservoir (9.5\%) and the lower section of the Soła River (9.3\%). The mean weight of the northern pike caught, considering Polish conditions, was relatively high at $1.72 \mathrm{~kg}$ (Wołos et al. 2019). In the Katowice district of the PAA, catches were registered by 30,683 anglers, and the total northern pike catch was $20,558 \mathrm{~kg}$, which, similarly to that in the Bielsko-Biała district of the PAA, was $9.0 \%$ of the weight of all the fish caught. However, northern pike shares were much higher in selected fishing grounds at $23.8 \%$ in the Chechło-Nakło Reservoir, 23.6\% in the Gzel Reservoir, and $23.5 \%$ in the Rogoźnik II Reservoir. The mean weight of northern pike caught was lower than that in the waters of the Bielsko-Biała district of the PAA at $1.46 \mathrm{~kg}$ (Wołos et al. 2018). In the waters of the Mazovian district of the PAA (central and northern Poland) and the largest in the country, which has the most diverse configuration of various water categories ranging from the largest dam reservoirs in Poland in Włocławek and Zegrze, the Vistula, Narew, and Bug rivers that are also the largest in Poland, and several dozen lakes, and trout and grayling rivers, 7,809 anglers registered catches. Northern pike catches were $13.9 \%$ of the total weight of the fish caught, and the mean individual weight of $1.80 \mathrm{~kg}$ was the highest among all PAA districts discussed in this study. Among the rivers fished by anglers, the largest shares of northern pike were recorded in the following streams: Nurzec (38.7\%), Orzyc (37.4\%), Brok (34.1\%), Bug (23.5\%), and Ełk (23.3\%). In turn, the highest percentage of northern pike caught in lakes occurred in the following fishing grounds located in the southern part of Masuria: Nożyce (40.4\%), Świętajno (Narty) (32.7\%), and Wałpusz (29.5\%) (Draszkiewicz-Mioduszewska and Wołos 2019). From the Torun district of the PAA, 11,435 anglers registered catches, and the total northern pike catch at over 200 different fishing grounds, but mostly in lakes, was $12,296 \mathrm{~kg}$, which was $15.3 \%$ of the weight of all fishes caught. The largest number of northern pike was recorded in lakes, with the highest shares of this species recorded in the following lakes: Studa (72\%), Księte (53.3\%), Szynwałd (53\%), Wieczno Południowe (47.1\%), Zbiczno (37.5\%), and Niskie Brodno (33.5\%). Among rivers, the Drwęca is noteworthy since $29 \%$ of catches were of northern pike and $8.8 \%$ were of sea trout. The Vistula is Poland's largest lowland river, and it also had a relatively high percentage of northern pike catches at $13.6 \%$. The mean individual weight of all registered northern pike was lower than that recorded in the waters of the Mazovian district of the PAA at $1.41 \mathrm{~kg}$ (Trella et al. 2019).

Since 2004, entities exploiting fisheries of flowing waters, which include flow-through lakes, rivers, and dam reservoirs, are required to submit to Stanisław Sakowicz Inland Fisheries Institute completed RRW-23 statistical questionnaires concerning, inter alia, information on the size and species structure of commercial catches, and, beginning in 2017, angling entities are also required to submit these. Because of the time-consuming work of collecting and analyzing data from catch registers, they 
are reported with a one-year delay as compared to data from commercial fisheries catches. Therefore, in 2019, users reported information on the results obtained from anglers in the 2017 season, and there were 319 such entities that exploited a total of 349,700 ha of flowing waters (Wołos and Draszkiewicz-Mioduszewska 2020). Calculations indicated that total angling catches were 3,230 tons, and at least 34 fish species were registered, most of which were by bream and roach, followed by northern pike and perch. The total reported northern pike weight was 507.4 tons at a yield of $1.45 \mathrm{~kg} \mathrm{ha}^{-1}$ and a share of $15.7 \%$ of the total catch. In the same year, commercial northern pike catches were 233 tons (10.6\% of all species caught) and the yield was 0.61 $\mathrm{kg} \mathrm{ha}^{-1}$, which means that, according to RRW-23 questionnaires, anglers recorded 2.4 times more northern pike in fisheries zones waters than did commercial fishers.

\section{How much northern pike do commercial fishers and anglers catch, or which data are the most probable?}

Determining actual commercial northern pike catches is not a problem, because the Department of Fisheries Bioeconomics, IFI receives detailed information every year from those authorized to exploit lake fisheries, including fisheries enterprises, PAA districts, private persons, national parks, and other entities, for a total lake surface area of 230,000 240,000 ha, which is, depending on the year of the research, $85-90 \%$ of the total area of the lakes exploited in Poland. The total weight of northern pike caught in 2018 by commercial lake fishers, after extrapolating this data to the total area of lakes exploited for fishing (270,000 ha), was estimated to be 233 tons. This value is identical to that reported for catches in the same year from all flowing waters including interconncetd lakes, rivers and dam reservoirs. Because not all users of fisheries zones waters returned the RRW-23 statistical questionnaire, the figure of 233 tons is slightly underestimated. Since the sample of entities exploiting these zones surveyed in 2018 included all large and medium-sized fisheries enterprises, all PAA districts, and over 200 users of districts that were usually small, an estimated total commercial catch of northern pike in Poland at no more than 250 tons is highly probable.

However, it is more difficult to calculate the real level of the total northern pike angling catches. Based on the information in the studies cited in the present study work, the final calculations are as follows:

- yield based on surveys from the Great Masurian Lakes (Wołos 1984) - $4.00 \mathrm{~kg} \mathrm{ha}^{-1}$;

- lake yield based on a survey study (Wołos et al. 2015) - $3.30 \mathrm{~kg} \mathrm{ha}^{-1}$;

- yield based on a nationwide survey study (Czarkowski et al. 2018) - $5.60 \mathrm{~kg} \mathrm{ha}^{-1}$;

- yield in fisheries zones waters based on RRW-23 statistical questionnaires (Wołos and Draszkiewicz-Mioduszewska 2020) - 1.45 kg ha $^{-1}$;

- actual yield of all waters exploited by anglers, assuming catches of all fish species of 13,000 tons and a $15.7 \%$ share of northern pike (Wołos and Draszkiewicz-Mioduszewska 2020) - $4.25 \mathrm{~kg} \mathrm{ha}^{-1}$.

The lowest yield $\left(1.45 \mathrm{~kg} \mathrm{ha}^{-1}\right)$ of fishing district waters calculated based on statistical questionnaires was underestimated because not all anglers returned their catch registers (e.g., following the 2017 season, only $35.6 \%$ did so in the Bielsko Biała district of the PAA, while $73.0 \%$ did so in the Katowice district of the PAA). This conclusion is all the more justified because in Poland (Czarkowski et al. 2018), as well as in most developed countries of the world (Arlinghaus et al. 2021), more and more anglers are practicing $\mathrm{C} \& \mathrm{R}$ fishing, and, in PAA waters these catches are not recorded in catch registers. The remaining yields are within the fairly narrow range of $3.30 \mathrm{~kg} \mathrm{ha}^{-1}$ to $5.60 \mathrm{~kg} \mathrm{ha}^{-1}$, and it can be assumed with high probability that a yield of about $4 \mathrm{~kg} \mathrm{ha}^{-1}$ is close to the actual one. This permits estimating total northern pike catches from the total surface area of waters exploited by anglers at about 2,000 tons, which is eightfold more than the catch obtained with commercial fishing gear (250 tons). 


\section{Conclusions}

The significant disproportion between catches of northern pike with commercial and angling fishing gears is quite understandable if we take into account the fact that we currently have more than a million anglers and about 400 commercial lake fishers. Importantly, on a national scale, anglers currently express the strongest preference for catching northern pike (Czarkowski et al. 2018). Let us add to this the fact that traditional fisheries management is conducted on about half of the total water surface area of Poland (excluding carp production ponds and some nature reserves), while angling pressure is exerted on almost the entire area of these waters (excluding the waters mentioned above). It must be emphasized at this point that the study results presented regarding northern pike angling catches were based on two methods, namely voluntary questionnaire studies and compulsory catch registers, and they are only estimates, which is the result of the advantages and disadvantages of the research methods applied. Many years of experience using these two methods permitted us to draw the following general conclusion; the results regarding the size of angling catches obtained based on voluntary surveys and interviews are usually three to four times higher than those obtained after the analysis of obligatory catch registers. Therefore, the method using catch registers we have provided permits a conclusive examination of qualitative factors, but it is insufficient to examine quantitative parameters (Wołos and Trella 2017). Therefore, the estimate presented in this study, which took into account the results of many other surveys, is an attempt to reach a scientifically justified compromise.

Author contributions. M.T. and A.W. analyzed the data, prepared the figures, wrote the paper. M.T. designed the survey, conducted the review of the literature, and followed up on the publication process. A.W. suggested the topic, collected data, corrected the paper, and approved the final manuscript.

The study was conducted under research grant S-014 for Stanisław Sakowicz Inland Fisheries Institute.
ORCID iD

Marek Trella iD https://orcid.org/0000-0003-3700-1771)

Arkadiusz Wołos iD https://orcid.org/0000-0002-6272-7614)

\section{References}

Antosiak, B. (1961). Northern pike (Esox lucius L.) growth in lakes near Węgorzewo. Rocz. Nauk Roln. 77-B-2, 579-602 (in Polish).

Arlinghaus, R., Aas, Ø., Alós, J., Arismendi, I., Bower, S., Carle, S., Czarkowski, T., Freire, K. M. F., Hu, J., Hunt, L. M., Lyach, R., Kapusta, A., Salmi, P., Schwab, A., Tsuboi, J., Trella, M., McPhee, D., Potts, W., Wołos, A., Yang, Z. (2021). Global Participation in and Public Attitudes Toward Recreational Fishing: International Perspectives and Developments, Reviews in Fisheries Science \& Aquaculture, 29:1, 58-95, DOI: 10.1080/23308249.2020.1782340

Bnińska, M., Wołos, A. (2001). Management of selected Polish commercial and recreational lake fisheries activities. Fisheries Management of Ecology, 8, 333-343.

Craig, J. F. (2008). A short review of northern pike ecology. Hydrobiologia 601, 5-16.

Czarkowski, T. K., Kapusta, A. (2016). Review of problems linked with managing northern pike (Esox lucius L.) populations with a particular focus on catching spawners. Komunikaty Rybackie, 3, 13-19 (in Polish).

Czarkowski, T. K., Wołos, A., Kapusta, A., Kupren K., Mickiewicz, M. (2018). Changes in Polish recreational fisheries over 40 years: Catches, opinions, preferences, and socioeconomic aspects of today's angler. In: Undertakings of fisheries enterprises in 2017 (Eds.) M. Mickiewicz, A. Wołos, Wydawnictwo IRS, Olsztyn, 99-121. (in Polish).

Draszkiewicz-Mioduszewska, H., Wołos, A. (2019). Assessment of recreational fisheries pressure and catches in waters exploited by the Mazovian district of the Polish Angling Association in 2017 - Report for the Mazovian district of the Polish Angling Association (typescript): 29 pp. (in Polish).

Donadi, S., Austin, Å. N., Bergström, U., Eriksson, B. K., Hansen, J. P., Jacobson, P., Sundblad, G., van Regteren, M., Eklöf, J. S. (2017). A cross-scale trophic cascade from large predatory fish to algae in coastal ecosystems. Proc. R. Soc. B: 28420170045. http://doi.org/10.1098/rspb.2017.0045

Eklöf, J.S., Sundblad, G., Erlandsson, M., Donadi, S., Hansen, J.P., Eriksson, B.K., Bergström, U. (2020). A spatial regime shift from predator to prey dominance in a large coastal ecosystem. Communications Biology, 3, 459. https://doi.org/10.1038/s42003-020-01180-0. 
Eriksson, B.K., Ljunggren, L., Sandström, A., Johansson, G., Mattila, J., Rubach, A., Råberg, S. Snickars, M. (2009). Declines in predatory fish promote bloom forming macroalgae. Ecological Applications, 19, 1975-1988. https://doi.org/10.1890/08-0964.1

Eriksson, B.K., Sieben, K., Eklöf, J., Ljunggren, L., Olsson, J., Casini, M., Bergström, U. (2011). Effects of altered offshore food webs on coastal ecosystems emphasize the need for cross-ecosystem management. Ambio, 40, 786. doi: 10.1007/s13280-011-0158-0

Forsman, A., Tibblin, P., Berggren, H., Nordahl, O., Koch-Schmidt, P., Larsson, P. (2015). Northern pike Esox lucius as an emerging model organism for studies in ecology and evolutionary biology: a review. Journal of Fish Biology, 87, 472-479.

Lampert, W., Sommer, U. (2001). Ecology of inland waters. Wyd. Nauk. PWN, Warszawa, 415 pp. (in Polish).

Larsson, P., Tibblin, P., Koch-Schmidt, P., Engstedt, O., Nilsson, J., Nordahl, O., Forsman, A. (2015). Ecology, evolution, and management strategies of northern pike populations in the Baltic Sea. Ambio, 44 (Suppl. 3), 451-461. doi: 10.1007/s13280-015-0664-6

Leopold, M., Bnińska, M. (1980). Angling, recreation, commercial fisheries and problems of water resources allocation (Ed.) J. H. Grover, Proceedings of technical consultation on allocation of fishery resources, Vichy, Auburn University, 212-221.

Leopold, M., Bnińska, M., Nowak, W. (1986). Commercial fish catches as an index of lake eutrophication. Arch. Hydrobiol. 106, 513-524.

Leopold, M., Bnińska, M. (1987). Assessment of recreational fisheries pressure on the stocks of selected fish species in Polish waters - Consequences of management. Rocz. Nauk. Rol. H 101 z. 2, 43-69 (in Polish).

Leopold, M., Bnińska, M., Wołos, A., Szlażyńska, K., Piskorski, P. (1988). Assessment of recreational fisheries exploitation of the waters of the Słupsk voivodeship based on fishing registration cards. State of the waters and guidelines for their management. Report for the Board of the Słupsk district of the Polish Angling Association, IFI, Olsztyn (typescript): 298 pp. (in Polish).

Leopold, M., Wołos, A. (1996). Analysis of the state of lake fisheries production in 1995. In: Lake fisheries. Status, conditions, perspectives (Ed.) A. Wołos. Wydawnictwo IRS, Olsztyn, 35-43. (in Polish).

Mehner, T., Arlinghaus, R., Berg, S., Dorner, H., Jacobsen, L., Kasprzak, P., Koschel, R., Schulze, T., Skov, C., Wolter, C., Wysujack, K. (2004). How to link biomanipulation and sustainable fisheries management: A step-by-step guideline for lakes of the European temperate zone. Fisheries Management of Ecology, 11, 261-275.

Mickiewicz, M. (2012). Value and structure of fish catches and stocking intensity in lake enterprises before and after fisheries ownership transfer in Poland. Archives of Polish Fisheries, 20, 77-83.

Mickiewicz, M. (2013). Economic effectiveness of stocking lakes in Poland. Archives of Polish Fisheries, 21, 323-329.

Mickiewicz, M., Wołos, A. (2012). Economic ranking of the importance of fish species to lake fisheries stocking management in Poland. Archives of Polish Fisheries, 20, 11-18.

Neumann, T. (2010). Climate-change effects on the Baltic Sea ecosystem: A model study. Journal of Marine Systems 81, 213-224.

Nilsson, J., Flink, H., Tibblin, P. (2019). Predator-prey role reversal may impair the recovery of declining northern pike populations. Journal og Animal Ecology, 2019, 88, 927-939. https://doi.org/10.1111/1365-2656.12981

Öhlund, G. (2012). Ecological and evolutionary effects of predation in environmental gradients. Dissertation thesis. Department of Ecology and Environmental Science, Umeå Universitet, 23 pp.

Report on the state of and perspectives for inland fisheries management (1981). Report for the Ministry of Agriculture and Food Management, IFI, Olsztyn (typescript): 33 pp. (in Polish).

State of and perspectives for inland fisheries in Poland (1986). Report for the Ministry of Agriculture and Food Management, IFI, Olsztyn (typescript): 44 pp. (in Polish).

Szczepkowski, M., Zakęś, Z., Kapusta, A., Szczepkowska, B., Hopko, M., Jarmołowicz, S., Kowalska, A., Kozłowski, M., Partyka, K., Piotrowska, I., Wunderlich, K. (2012). Growth and survival in earthen ponds of different sizes of juvenile northern pike reared in recirculating aquaculture systems. Archives of Polish Fisheries 20, 267-274.

Szczepkowski, M., Zakęś, Z., Szczepkowska, B., Piotrowska, I., Kozłowski, M., Wunderlich, K., Kapusta, A. (2015). Tag retention, growth rate, and survival of juvenile pike tagged with visible implant elastomer and coded wire tags. Bulgarian Journal of Agricultural Science, 21(1), 12-16.

Traczuk, P. (2013). Characteristics of great cormorant breeding colonies in northeastern Poland. In: Sustainable exploitation of fishery stocks and their state in 2012 (Ed.) M. Mickiewicz, Wydawnictwo IRS, Olsztyn, 81-92 (in Polish).

Trella, M., Czerwiński, T., Wołos, A. (2019). Determinants of fisheries management in dam reservoirs in Central-Eastern Europe under the influence of climate change. Fisheries \& Aquatic Life 27, 208-223.

Trella, M., Wołos, A., Chmielewski, H., Grzegorczyk, J., Miętus, A. (2019). Recreational fisheries catches in waters exploited by the Torun district of the Polish Angling Association in 2017. Wyd. SW Edycja, Olsztyn, 114 pp. (in Polish). 
Wake, B. (2012). Modelling: Climate and Baltic Sea nutrients. Nature Climate Change 2, 394.

Wołos, A. (1984). Declines in commercial catches of northern pike in the Great Masurian Lakes region. An attempt to determine the size of recreational catches. Gosp. Ryb. 3, 21-22 (in Polish).

Wołos, A., Grabowska, K. (1990). Assessment of the recreational fisheries exploitation of the waters of the Suwałki district of the Polish Angling Association based on catch records from 1988. Analysis of commercial-recreational fisheries management, water status, and guidelines for their management. Report for the Board of the Suwałki district of the Polish Angling Association, IFI, Olsztyn (typescript): 55 pp. (in Polish).

Wołos, A. (1991). Anglers' opinions as to the quality of the fishing and the fishery management in selected Polish waters. In: Catch effort sampling strategies. Their application in freshwater fisheries management (Ed.) I.G. Cowx, Fishing News Books, 134-142.

Wołos, A., Piskorski, P. (1991). Anglers' catches as an illustration of the fish community structures, angling pressure and angling regulations based on inland waters in Krosno Region, Poland. In: Catch effort sampling strategies. Their application in freshwater fisheries management (Ed.) I.G. Cowx, Fishing New Books, 166-176.

Wołos, A. (1992). Development of research methods and their application in determining the principles of lake management for recreational fisheries. Doctoral dissertation, IFI, Olsztyn, 62 pp. (in Polish).

Wołos, A. (1994). Recreational fisheries as an element of lake exploitation. In: Current issues in lake fisheries (Ed.) A. Wołos, Wydawnictwo IRS, Olsztyn, 119-132 (in Polish).

Wołos, A., Teodorowicz, M., Brylski, H. (1998). Socio-economic analysis of recreational fisheries in 2 departments of the Polish Anglers Association, based on the results of the registration of anglers' catches. In: Recreational fisheries. Social, economic and management aspects (Eds) P. Hickley and H. Tompkins, Fishing New Books, Blackwell Scientific Publications, Oxford, 36-47.

Wołos, A. (2000). Economic significance of recreational fisheries in entities authorized to exploit lake fisheries. Archives of Polish Fisheries, 8, 1: 54.

Wołos, A., Mickiewicz, M. (2002). Objectives and methods of recording recreational fisheries. Brochure for the Board of the Polish Angling Association, SPW Edycja, Olsztyn, 36 pp. (in Polish).

Wołos, A., Mioduszewska, H., Czerwiński, T., Mickiewicz, M., Chmielewski, H., Grzegorczyk, J. (2006). Recreational catches in waters used by the Jelenia Góra, Legnica, Wałbrzych and Wrocław districts of the Polish Angling
Association in 2004. SPW Edycja, Olsztyn: 164 pp. (in Polish).

Wołos, A., Draszkiewicz-Mioduszewska, H., Trella, M. (2015). Characteristics of the pressure and recreational fisheries in lakes exploited by fisheries enterprises in 2013. In: Sustainable exploitation of fisheries resources and their state in 2014 (Eds.) M. Mickiewicz, A. Wołos, Wydawnictwo IRS, Olsztyn, 159-171 (in Polish).

Wołos, A., Trella, M. (2017). Mandatory registration of recreational fisheries - data reliability and usefulness in determining the state of fish resources. In: Recreational fishers 2016 - The role of fisheries management in the waters of the Polish Angling Association and principles of sustainable development (Ed.) M. Mizieliński. Wydawnictwo Wieś Jutra Sp. z o.o., Warszawa, 191-210 (in Polish).

Wołos, A. (2018). Fisheries management in Lake Śniardwy. Multidimensional impressions based on economic data and two days of angling in September 2018. Komunikaty Rybackie, 5, 25-33 (in Polish).

Wołos, A., Czarkowski, T.K., Draszkiewicz-Mioduszewska, H., Chmielewski, H., Miętus, A. (2018). Size and structure of recreational fisheries catches in the waters of the Katowice district of the Polish Angling Association in 2017. Using statistical methods to evaluate the effectiveness of restocking with valuable fish species. SW Edycja, Olsztyn: 173 pp. (in Polish).

Wołos, A. (2019a). Size and characteristics of lake fishing production in 2018. In: Activities of fishing and angling entities in 2018. Economic and environmental conditions (Eds.) M. Mickiewicz, A. Wołos, Wydawnictwo IRS, Olsztyn, 9-19 (in Polish).

Wołos, A. (2019b). Information on inland fishing in the Warmian-Masurian Voivodeship in 2018. Study for the Marshal's Office of the Warmian-Masurian Voivodeship in Olsztyn in 2018. IFI, Olsztyn (typescript): 2 pp. (in Polish).

Wołos, A., Draszkiewicz-Mioduszewska, H., Chmielewski H. (2019). Recreational catches in waters exploited by the Bielsko-Biała district of the Polish Angling Association in 2017. SW Edycja, Olsztyn: 37 pp. (in Polish).

Wołos, A., Draszkiewicz-Mioduszewska, H. (2020). Fisheries management in inland surface waters in 2018. Part 1. Authorized to fish, fisheries zones, commercial catches, employment, and recreational catches. Komunikaty Rybackie, 1, 13-22 (in Polish).

Zakęś, Z., Szczepkowski, M., Kapusta, A., Rożyński, M., Stawecki, K., Pyka, J., Szczepkowska B., Wunderlich, K., Kozłowski, M., Kowalska, A., Hopko M. (2015). From aquaculture to nature. Developing alternative methods for managing the fisheries of predatory lake fish (Eds.) Z. Zakęś, M. Szczepkowski, Wydawnictwo IRS, Olsztyn, 224 pp. 